\title{
Studies on the Synthesis of Apoptolidin A. 1. Synthesis of the $\mathrm{C}(1)-\mathrm{C}(11)$ Fragment
}

\author{
Masaki Handa, ${ }^{\text {a }}$ Karl A. Scheidt, ${ }^{\mathrm{b}}$ Martin Bossart, ${ }^{\mathrm{b}}$ Nan Zheng, and William R. Roush ${ }^{*^{\mathrm{a}}}$

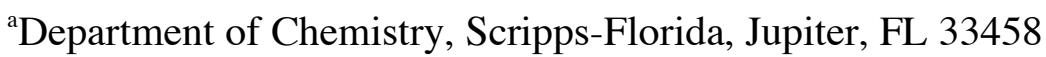 \\ ${ }^{\mathrm{b}}$ Department of Chemistry, University of Michigan, Ann Arbor, MI 48109 \\ e-mail: roush@scripps.edu
}

Table of Contents:

General Experimental Details

SI-2

Experimental Procedures and Characterization Data:

Compound 11

SI-2

Compound 12

SI-3

Compound 9

SI-3

Compound 16

SI-4

Compound 17

SI-5

Compound 18

SI-5

Compound 8

SI-6

Compound 20

SI-7

Compound 21

SI-7

Compound 7

SI-8

Compound 24

SI-8

Compound 25

SI-9

Compound 26

SI-10 
General Experimental Details. All reaction solvents were purified before use. Tetrahydrofuran, dichloromethane, diethyl ether, and toluene were purified by passing through a solvent column composed of activated A-1 alumina. Unless indicated otherwise, all reactions were conducted under an atmosphere of argon using flame-dried glassware. Four $\AA$ molecular sieves were activated under high vacuum with flame drying immediately prior to use.

Proton nuclear magnetic resonance ( ${ }^{1} \mathrm{H}$ NMR) spectra were recorded on a commercial instrument at $400 \mathrm{MHz}$. Carbon-13 nuclear magnetic resonance $\left({ }^{13} \mathrm{C}\right.$ NMR) spectra were recorded at $100 \mathrm{MHz}$. The proton signal for residual non-deuterated solvent $\left(\delta 7.26\right.$ for $\left.\mathrm{CHCl}_{3}\right)$ was used as an internal reference for ${ }^{1} \mathrm{H}$ NMR spectra. For ${ }^{13} \mathrm{C}$ NMR spectra, chemical shifts are reported relative to the 877.0 resonance of $\mathrm{CHCl}_{3}$. Coupling constants are reported in $\mathrm{Hz}$. Infrared (IR) spectra were recorded as films on a commercial FTIR instrument. Optical rotations were measured on a commercially available polarimeter using a quartz cell with $1 \mathrm{~mL}$ capacity and a $10 \mathrm{~cm}$ path length. Mass spectra were recorded on a high resolution mass spectrometer in electron impact mode.

Analytical thin layer chromatography (TLC) was performed on Kieselgel $60 \mathrm{~F}_{254}$ glass plates precoated with a $0.25 \mathrm{~mm}$ thickness of silica gel. Column chromatography was generally performed using Kieselgel 60 (230-400 mesh) silica gel.

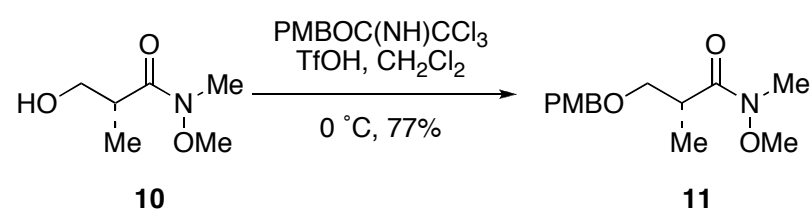

(R)-N-Methoxy-3-(4-methoxy-benzyloxy)-2,N-dimethyl-propionamide (11). To a slurry of sodium hydride $(102 \mathrm{mg}, 2.55 \mathrm{mmol}, 60 \%)$ in $\mathrm{Et}_{2} \mathrm{O}(17.7 \mathrm{~mL})$ was added $p$-methoxybenzyl alcohol (3.18 $\mathrm{mL}, 25.5 \mathrm{mmol}$ ), and the mixture was stirred for $1 \mathrm{~h}$ at room temperature. The solution was cooled to $0{ }^{\circ} \mathrm{C}$, and trichloroacetonitrile $(2.56 \mathrm{~mL}, 25.5 \mathrm{mmol})$ was slowly added. The mixture was allowed to warm to room temperature and stirred for $1 \mathrm{~h}$. The crude mixture was concentrated, diluted with hexane/ $\mathrm{MeOH}(98: 2)$, filtrated, and concentrated to give the crude trichloroacetimidate.

To a mixture of a primary alcohol $10(2.03 \mathrm{~g}, 13.8 \mathrm{mmol})$ and the above trichloroacetimidate in $\mathrm{CH}_{2} \mathrm{Cl}_{2}(71.0 \mathrm{~mL})$ was added catalytic trifluoromethanesulfonic acid $(63 \mu \mathrm{L}, 710 \mu \mathrm{mol})$. The resulting mixture was stirred for $2 \mathrm{~h}$ at $0{ }^{\circ} \mathrm{C}$, then was diluted with saturated aqueous $\mathrm{NaHCO}_{3}$. The organic layer was separated and the aqueous layer was extracted with $\mathrm{CHCl}_{3}$. The combined organic layers were washed with brine, dried, and concentrated. The crude product was purified by flash chromatography (hexane : EtOAc = 5:1 to $1: 1)$ to give the PMB ether $11(2.86 \mathrm{~g}, 10.7 \mathrm{mmol}, 77 \%)$ as a slightly yellow oil: $[\alpha]_{\mathrm{D}}{ }^{23}=-3.04^{\circ}\left(c 1.02, \mathrm{CHCl}_{3}\right) ;{ }^{1} \mathrm{H} \mathrm{NMR}\left(400 \mathrm{MHz}, \mathrm{CDCl}_{3}\right) \delta 7.23(\mathrm{~d}, J=8.7$ $\mathrm{Hz}, 2 \mathrm{H}), 6.86(\mathrm{~d}, J=8.7 \mathrm{~Hz}, 2 \mathrm{H}), 4.48(\mathrm{~d}, J=11.6 \mathrm{~Hz}, 1 \mathrm{H}), 4.40(\mathrm{~d}, J=11.6 \mathrm{~Hz}, 1 \mathrm{H}), 3.80(\mathrm{~s}, 3 \mathrm{H})$, 
3.69 (s, 3H), $3.68(\mathrm{~m}, 1 \mathrm{H}), 3.39(\mathrm{dd}, J=8.9,5.9 \mathrm{~Hz}, 1 \mathrm{H}), 3.25(\mathrm{~m}, 1 \mathrm{H}), 3.20(\mathrm{~s}, 3 \mathrm{H}), 1.10(\mathrm{~d}, J=6.9$ $\mathrm{Hz}, 3 \mathrm{H}) ;{ }^{13} \mathrm{C}$ NMR $\left(100 \mathrm{MHz}, \mathrm{CDCl}_{3}\right.$ ) $\delta$ 175.8, 159.0, 130.4, 129.0 (2C), 113.6 (2C), 72.7, 72.2, 61.4, 55.1, 35.7, 32.0, 14.1; IR (neat) 3497, 2937, 1659, 1513, 1464, 1248, 1174, 1098, 1034, 994, $820 \mathrm{~cm}^{-1}$; HRMS (ES+) $m / z$ for $\mathrm{C}_{14} \mathrm{H}_{21} \mathrm{NNaO}_{4}[\mathrm{M}+\mathrm{Na}]^{+}$calcd 290.1368, found 290.1368.

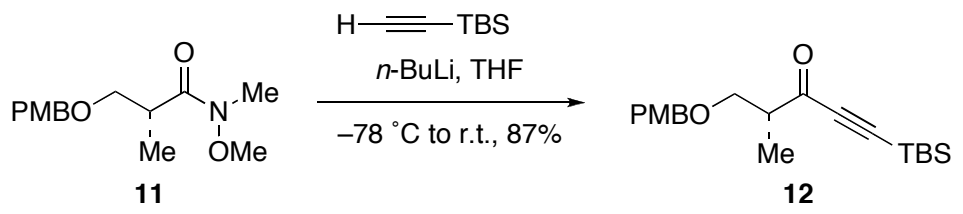

(R)-1-(tert-Butyl-dimethyl-silanyl)-5-(4-methoxy-benzyloxy)-4-methyl-pent-1-yn-3-one (12). To a solution of (tert-butyldimethylsilyl)acetylene $(2.53 \mathrm{~mL}, 13.5 \mathrm{mmol})$ in THF $(38.5 \mathrm{~mL})$ was added $n$-butyllithium in hexane $(5.63 \mathrm{~mL}, 13.5 \mathrm{mmol}, 2.41 \mathrm{M})$ at $-78{ }^{\circ} \mathrm{C}$. The resultant mixture was stirred for $5 \mathrm{~min}$ at $-78^{\circ} \mathrm{C}$, then allowed to warm to $0{ }^{\circ} \mathrm{C}$, and stirred for $15 \mathrm{~min}$. The mixture was taken back to $-78{ }^{\circ} \mathrm{C}$, then the Weinreb amide $11(2.59 \mathrm{~g}, 9.70 \mathrm{mmol})$ in THF (10 mL) was added slowly. The mixture was allowed to warm to room temperature and stirred for $25 \mathrm{~min}$. The mixture was then diluted saturated aqueous $\mathrm{NH}_{4} \mathrm{Cl}$ at $0{ }^{\circ} \mathrm{C}$. The organic layer was separated and the aqueous layer was extracted with $\mathrm{Et}_{2} \mathrm{O}$. The combined organic layers were washed with brine, dried, and concentrated. The crude product was purified by flash chromatography (hexane : EtOAc $=30: 1$ ) to give the alkynyl ketone 12 (2.94 g, $8.49 \mathrm{mmol}, 87 \%)$ as a yellow oil: $[\alpha]_{\mathrm{D}}{ }^{23}=+1.48^{\circ}\left(c 1.08, \mathrm{CHCl}_{3}\right) ;{ }^{1} \mathrm{H}$ NMR $(400$ $\left.\mathrm{MHz}, \mathrm{CDCl}_{3}\right) \delta 7.23(\mathrm{~d}, J=8.5 \mathrm{~Hz}, 2 \mathrm{H}), 6.86(\mathrm{~d}, J=8.5 \mathrm{~Hz}, 2 \mathrm{H}), 4.45(\mathrm{~s}, 2 \mathrm{H}), 3.80(\mathrm{~s}, 3 \mathrm{H}), 3.74(\mathrm{dd}$, $J=9.4,6.8 \mathrm{~Hz}, 1 \mathrm{H}), 3.56(\mathrm{dd}, J=9.4,5.7 \mathrm{~Hz}, 1 \mathrm{H}), 2.87(\mathrm{~m}, 1 \mathrm{H}), 1.20(\mathrm{~d}, J=7.1 \mathrm{~Hz}, 3 \mathrm{H}), 0.96(\mathrm{~s}, 9 \mathrm{H})$, 0.17 (s, 6H); ${ }^{13} \mathrm{C}$ NMR (100 MHz, $\left.\mathrm{CDCl}_{3}\right) \delta 189.3,159.1,130.1,129.1$ (2C), 113.7 (2C), 101.7, 97.7, 72.9, 70.9, 55.2, 48.9, 25.9 (3C), 16.5, 13.1, -5.22 (2C); IR (neat) 2932, 2147, 1677, 1513, 1249, 1072, 828, $780 \mathrm{~cm}^{-1}$; HRMS (ES+) $\mathrm{m} / z$ for $\mathrm{C}_{20} \mathrm{H}_{30} \mathrm{NaO}_{3} \mathrm{Si}[\mathrm{M}+\mathrm{Na}]^{+}$calcd 369.1862, found 369.1853.
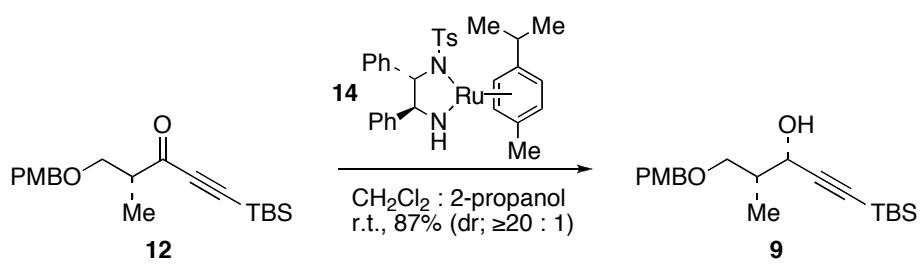

(3S,4R)-1-(tert-Butyl-dimethyl-silanyl)-5-(4-methoxy-benzyloxy)-4-methyl-pent-1-yn-3-ol (9). To a solution of alkynyl ketone 12 (1.63 g, $4.71 \mathrm{mmol})$ in $\mathrm{CH}_{2} \mathrm{Cl}_{2}(353 \mathrm{~mL})$ and 2-propanol (118 mL) was added Noyori's catalyst $\mathbf{1 4}^{1}$ in 2-propanol $(6.28 \mathrm{~mL}$ of $0.03 \mathrm{M}$ stock solution, $188 \mu \mathrm{mol})$ at room temperature. The resultant mixture was stirred for $2 \mathrm{~h}$ at ambient temperature, and then filtered through silica gel. The cake was washed with $\mathrm{CH}_{2} \mathrm{Cl}_{2}$, and the filtrate was concentrated. The crude product was purified by flash chromatography (hexane : EtOAc $=15: 1$ to $5: 1$ ) to give the propargylic alcohol 9 $(1.43 \mathrm{~g}, 4.11 \mathrm{mmol}, 87 \%)$ as a colorless oil: $[\alpha]_{\mathrm{D}}{ }^{23}=-45.3^{\circ}\left(c 1.07, \mathrm{CHCl}_{3}\right) ;{ }^{1} \mathrm{H} \mathrm{NMR}(400 \mathrm{MHz}$, $\left.\mathrm{CDCl}_{3}\right) \delta 7.25(\mathrm{~d}, J=8.5 \mathrm{~Hz}, 2 \mathrm{H}), 6.87(\mathrm{~d}, J=8.5 \mathrm{~Hz}, 2 \mathrm{H}), 4.48(\mathrm{~d}, J=11.3 \mathrm{~Hz}, 1 \mathrm{H}), 4.42(\mathrm{~d}, J=11.3$ 
$\mathrm{Hz}, 1 \mathrm{H}), 4.41(\mathrm{dd}, J=8.6,3.3 \mathrm{~Hz}, 1 \mathrm{H}), 3.80(\mathrm{~s}, 3 \mathrm{H}), 3.71(\mathrm{dd}, J=9.4,9.3 \mathrm{~Hz}, 1 \mathrm{H}), 3.63(\mathrm{~d}, J=8.6 \mathrm{~Hz}$, $1 \mathrm{H}), 3.51(\mathrm{dd}, J=9.0,4.4 \mathrm{~Hz}, 1 \mathrm{H}), 2.26(\mathrm{~m}, 1 \mathrm{H}), 0.94(\mathrm{~s}, 9 \mathrm{H}), 0.91(\mathrm{~d}, J=7.0 \mathrm{~Hz}, 3 \mathrm{H}), 0.12(\mathrm{~s}, 6 \mathrm{H})$; ${ }^{13} \mathrm{C}$ NMR (100 MHz, $\mathrm{CDCl}_{3}$ ) $\delta$ 159.3, 129.8, 129.3 (2C), 113.8 (2C), 105.5, 88.3, 73.3, 73.2, 67.3, 55.2, 38.5, 26.1 (3C), 16.4, 12.9, -4.60, -4.63; IR (neat) 3468, 2930, 2170, 1613, 1514, 1249, 1090, 1036, 827, $776 \mathrm{~cm}^{-1}$; HRMS (ES+) $\mathrm{m} / z$ for $\mathrm{C}_{20} \mathrm{H}_{32} \mathrm{NaO}_{3} \mathrm{Si}[\mathrm{M}+\mathrm{Na}]^{+}$calcd 371.2018, found 371.2019.
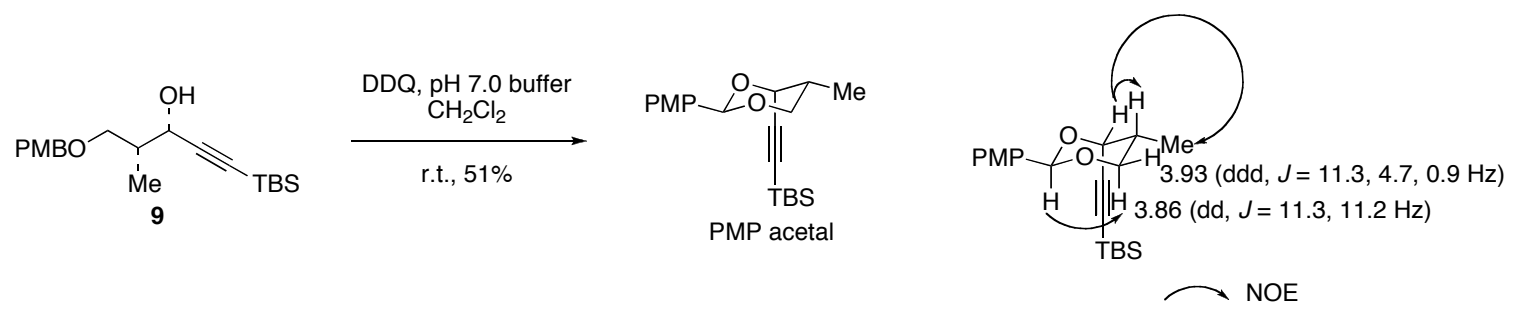

tert-Butyl-[(2R,4S,5R)-2-(4-methoxy-phenyl)-5-methyl-[1,3]dioxan-4-ylethynyl]-dimethylsilane. To a mixture of propargyl alcohol $9(45.7 \mathrm{mg}, 131 \mu \mathrm{mol})$ in $\mathrm{CH}_{2} \mathrm{Cl}_{2}(2.6 \mathrm{~mL})$ and $\mathrm{pH} 7.0$ buffer $(520 \mu \mathrm{L})$ was added DDQ $(59.6 \mathrm{mg}, 262 \mu \mathrm{mol})$ at room temperature. The resultant mixture was stirred for $6 \mathrm{~h}$. Additional DDQ $(59.6 \mathrm{mg}, 262 \mu \mathrm{mol})$ was added, and the mixture was stirred for another $14 \mathrm{~h}$. The mixture was diluted with $\mathrm{CHCl}_{3}$ and saturated aqueous $\mathrm{NaHCO}_{3}$ was added. The organic layer was separated and the aqueous layer was extracted with $\mathrm{CHCl}_{3}$. The combined organic layers were washed with brine, dried, and concentrated. The crude product was purified by flash chromatography (hexane $:$ EtOAc $=30: 1)$ to give the acetal formulated above $(23.2 \mathrm{mg}, 67.0 \mu \mathrm{mol}$, $51 \%$ ) as a colorless solid: $[\alpha]_{\mathrm{D}}{ }^{23}=-34.1^{\circ}\left(c 1.93, \mathrm{CHCl}_{3}\right) ; \mathrm{mp} 52^{\circ} \mathrm{C} ;{ }^{1} \mathrm{H} \mathrm{NMR}\left(400 \mathrm{MHz}, \mathrm{CDCl}_{3}\right) \delta$ $7.41(\mathrm{~d}, J=8.7 \mathrm{~Hz}, 2 \mathrm{H}), 6.89(\mathrm{~d}, J=8.7 \mathrm{~Hz}, 2 \mathrm{H}), 5.98(\mathrm{~s}, 1 \mathrm{H}), 4.84(\mathrm{~d}, J=5.1 \mathrm{~Hz}, 1 \mathrm{H}), 3.93$ (ddd, $J=$ 11.3, 4.7, $0.9 \mathrm{~Hz}, 1 \mathrm{H}), 3.86$ (dd, $J=11.3,11.2 \mathrm{~Hz}, 1 \mathrm{H}), 3.80$ (s, 3H), 2.42 (m, 1H), 0.99 (s, 9H), 0.89 $(\mathrm{d}, J=6.9 \mathrm{~Hz}, 3 \mathrm{H}), 0.17$ (s, 3H), $0.16(\mathrm{~s}, 3 \mathrm{H}) ;{ }^{13} \mathrm{C} \mathrm{NMR}\left(100 \mathrm{MHz}, \mathrm{CDCl}_{3}\right) \delta 159.9,130.7,127.5(2 \mathrm{C})$, 113.6 (2C), 100.8, 95.4, 93.5, 70.6, 69.3, 55.3, 32.4, 26.1 (3C), 16.5, 12.7, -4.66, -4.68; IR (neat) 2955, 2168, 1615, 1519, 1251, 1117, 1073, 985, $825 \mathrm{~cm}^{-1}$; HRMS (ES+) $m / z$ for $\mathrm{C}_{20} \mathrm{H}_{31} \mathrm{O}_{3} \mathrm{Si}[\mathrm{M}+\mathrm{H}]^{+}$calcd 347.2042, found 347.2027.

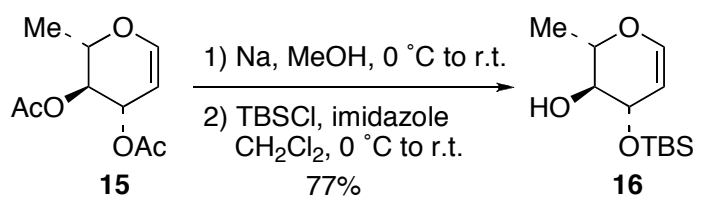

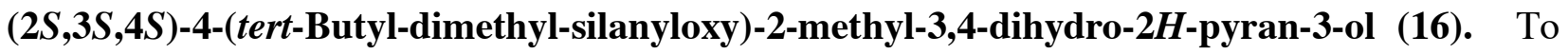
a methanol $(141 \mathrm{~mL})$ solution of L-di- $O$-acetyl-rhamnal $(\mathbf{1 5})(6.05 \mathrm{~g}, 28.2 \mathrm{mmol})$ was added sodium $(65.0 \mathrm{mg}, 2.82 \mathrm{mmol})$ at $0{ }^{\circ} \mathrm{C}$. The resultant mixture was allowed to warm to room temperature and stirred for $70 \mathrm{~min}$. Dry ice was then added to the mixture, which was subsequently concentrated. The residue was diluted with $\mathrm{CH}_{2} \mathrm{Cl}_{2}$ and $\mathrm{Na}_{2} \mathrm{SO}_{4}$ was added. The mixture was filtered and concentrated. The crude product was used in next reaction without purification. 
To a solution of the above crude L-rhamnal in $\mathrm{CH}_{2} \mathrm{Cl}_{2}(120 \mathrm{~mL})$ was added imidazole $(3.94 \mathrm{~g}$, $57.9 \mathrm{mmol})$ and $\mathrm{TBSCl}(4.36 \mathrm{~g}, 28.9 \mathrm{mmol})$ at $0{ }^{\circ} \mathrm{C}$. The resultant mixture was stirred for $10 \mathrm{~min}$, then allowed to warm to room temperature and stirred for $20 \mathrm{~h}$. The mixture was immersed in an ice bath, then saturated aqueous $\mathrm{NH}_{4} \mathrm{Cl}$ was added. The organic layer was separated and the aqueous layer was extracted with $\mathrm{CHCl}_{3}$. The combined organic layers were washed with brine, dried, and concentrated. The crude product was purified by flash chromatography (hexane : EtOAc $=20: 1$ ) to give TBS ether $16(5.34 \mathrm{~g}, 21.8 \mathrm{mmol}, 77 \%)$ as a colorless oil: $[\alpha]_{\mathrm{D}}{ }^{23}=+72.3^{\circ}\left(c 1.38, \mathrm{CHCl}_{3}\right) ;{ }^{1} \mathrm{H} \mathrm{NMR}(400 \mathrm{MHz}$, $\left.\mathrm{CDCl}_{3}\right) \delta 6.24(\mathrm{dd}, J=6.1,1.1 \mathrm{~Hz}, 1 \mathrm{H}), 4.61(\mathrm{dd}, J=6.1,2.2 \mathrm{~Hz}, 1 \mathrm{H}), 4.19(\mathrm{~m}, 1 \mathrm{H}), 3.89(\mathrm{dq}, J=9.0$, $6.4 \mathrm{~Hz}, 1 \mathrm{H}), 3.45$ (m, 1H), 2.22 (brs, 1H), 1.36 (d, J = 6.4 Hz, 3H), 0.90 (s, 9H), $0.11(\mathrm{~s}, 6 \mathrm{H}) ;{ }^{13} \mathrm{C}$ NMR $\left(100 \mathrm{MHz}, \mathrm{CDCl}_{3}\right) \delta$ 143.6, 103.4, 74.8, 74.3, 70.4, 25.8 (3C), 18.0, 17.2, -4.34, -4.55; IR (neat) 3468, 2931, 1646, 1253, 1108, 1085, 1048, 880, 837, $777 \mathrm{~cm}^{-1}$; HRMS (ES+) $m / z$ for $\mathrm{C}_{12} \mathrm{H}_{24} \mathrm{O}_{3} \mathrm{NaSi}[\mathrm{M}+\mathrm{Na}]^{+}$ calcd 267.1392, found 267.1377.

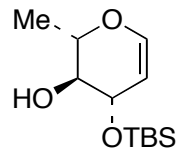

16

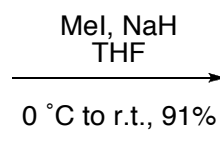

C to r.t., $91 \%$

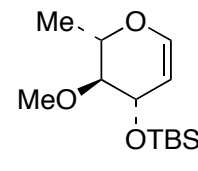

17

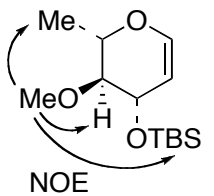

NOE

tert-Butyl-((2S,3S,4S)-3-methoxy-2-methyl-3,4-dihydro-2H-pyran-4-yloxy)-dimethyl-silane (17). To a solution of the TBS ether $16(5.09 \mathrm{~g}, 20.8 \mathrm{mmol})$ in THF (104 $\mathrm{mL})$ was added iodomethane $(26.0 \mathrm{~mL}, 417 \mathrm{mmol})$ and sodium hydride $(751 \mathrm{mg}, 31.3 \mathrm{mmol})$ at $0{ }^{\circ} \mathrm{C}$. The resultant mixture was allowed to warm to room temperature and stirred for $3 \mathrm{~h}$. The mixture was immersed in an ice bath, then saturated aqueous $\mathrm{NH}_{4} \mathrm{Cl}$ was added. The organic layer was extracted with $\mathrm{Et}_{2} \mathrm{O}$, washed with brine, dried, and concentrated. The crude product was purified by flash chromatography (hexane : EtOAc $=50: 1$ to $30: 1)$ to give the methyl ether $17(4.92 \mathrm{~g}, 19.0 \mathrm{mmol}, 91 \%)$ as a colorless oil: $[\alpha]_{\mathrm{D}}{ }^{23}$ $=+55.0^{\circ}\left(c 1.53, \mathrm{CHCl}_{3}\right) ;{ }^{1} \mathrm{H} \mathrm{NMR}\left(400 \mathrm{MHz}, \mathrm{CDCl}_{3}\right) \delta 6.25(\mathrm{dd}, J=6.1,1.3 \mathrm{~Hz}, 1 \mathrm{H}), 4.60(\mathrm{dd}, J=$ 6.1, $2.5 \mathrm{~Hz}, 1 \mathrm{H}), 4.24(\mathrm{~m}, 1 \mathrm{H}), 3.88(\mathrm{dq}, J=8.6,6.5 \mathrm{~Hz}, 1 \mathrm{H}), 3.56(\mathrm{~s}, 3 \mathrm{H}), 3.04(\mathrm{dd}, J=8.7,6.4 \mathrm{~Hz}$, $1 \mathrm{H}), 1.37(\mathrm{~d}, J=6.5 \mathrm{~Hz}, 3 \mathrm{H}), 0.91(\mathrm{~s}, 9 \mathrm{H}), 0.12(\mathrm{~s}, 3 \mathrm{H}), 0.11(\mathrm{~s}, 3 \mathrm{H}) ;{ }^{13} \mathrm{C} \mathrm{NMR}\left(100 \mathrm{MHz}, \mathrm{CDCl}_{3}\right) \delta$ 143.3, 103.8, 84.0, 73.8, 69.3, 60.4, 25.8 (3C), 18.0, 17.2, -4.52, -4.74; IR (neat) 2931, 1650, 1250, $1112,1049,880,838,776 \mathrm{~cm}^{-1}$; HRMS (ES+) $\mathrm{m} / z$ for $\mathrm{C}_{13} \mathrm{H}_{26} \mathrm{O}_{3} \mathrm{NaSi}[\mathrm{M}+\mathrm{Na}]^{+}$calcd 281.1549, found 281.1543.
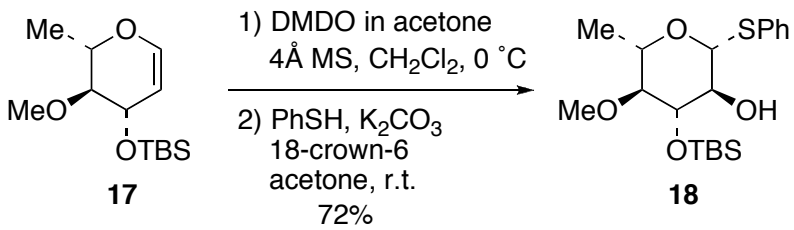

$(2 R, 3 S, 4 S, 5 S, 6 S)-4-($ tert-Butyl-dimethyl-silanyloxy)-5-methoxy-6-methyl-2-phenylsulfanyltetrahydro-pyran-3-ol (18). To a suspension of rhamnal derivative 17 (421 mg, $1.63 \mathrm{mmol})$ and $4 \AA$ 
molecular sieves $(840 \mathrm{mg})$ in $\mathrm{CH}_{2} \mathrm{Cl}_{2}(16.3 \mathrm{~mL})$ was added dimethyl dioxirane ${ }^{2}(27.2 \mathrm{~mL}$, ca $0.06 \mathrm{M})$ in acetone at $0{ }^{\circ} \mathrm{C}$. The resultant mixture was stirred for $10 \mathrm{~min}$ at $0{ }^{\circ} \mathrm{C}$, and then filtered. The filtrate was concentrated. The crude product was used in the next reaction without purification.

A mixture of thiophenol $(835 \mu \mathrm{L}, 8.17 \mathrm{mmol}), \mathrm{K}_{2} \mathrm{CO}_{3}(2.26 \mathrm{~g}, 16.3 \mathrm{mmol})$, and 18-crown-6 $(43.1 \mathrm{mg}, 163 \mu \mathrm{mol})$ in acetone $(50.0 \mathrm{~mL})$ was stirred under reflux for $2 \mathrm{~h}$. The mixture was cooled to room temperature and a solution of the crude epoxide from the previous step in acetone $(4.4 \mathrm{~mL})$ was added. The resultant mixture was stirred for $2 \mathrm{~h}$, and then filtered. The filtrate was evaporated, and the residue was dissolved in EtOAc. The solution was washed with aqueous $\mathrm{NaOH}$ and with brine, dried, and concentrated. The crude product was purified by flash chromatography (hexane $:$ EtOAc $=50: 1$ ) to give thioglycoside $18(451 \mathrm{mg}, 1.17 \mathrm{mmol}, 72 \%)$ as a colorless syrup: $[\alpha]_{\mathrm{D}}{ }^{23}=+43.0^{\circ}(c) 1.28$, $\left.\mathrm{CHCl}_{3}\right) ;{ }^{1} \mathrm{H} \mathrm{NMR}\left(400 \mathrm{MHz}, \mathrm{CDCl}_{3}\right) \delta$ 7.50-7.55 (m, 2H), 7.27-7.34 (m, 3H), $4.47(\mathrm{~d}, J=9.8 \mathrm{~Hz}, 1 \mathrm{H})$, $3.50(\mathrm{~s}, 3 \mathrm{H}), 3.50(\mathrm{~m}, 1 \mathrm{H}), 3.31(\mathrm{~m}, 2 \mathrm{H}), 2.74(\mathrm{dd}, J=9.3,8.9 \mathrm{~Hz}, 1 \mathrm{H}), 2.33(\mathrm{~d}, J=1.7 \mathrm{~Hz}, 1 \mathrm{H}), 1.36$ $(\mathrm{d}, J=6.1 \mathrm{~Hz}, 3 \mathrm{H}), 0.92(\mathrm{~s}, 9 \mathrm{H}), 0.13(\mathrm{~s}, 6 \mathrm{H}) ;{ }^{13} \mathrm{C} \mathrm{NMR}\left(100 \mathrm{MHz}, \mathrm{CDCl}_{3}\right) \delta 132.7,132.3(2 \mathrm{C}), 128.9$ (2C), 127.8, 88.3, 85.7, 78.4, 75.9, 73.2, 61.2, 25.9 (3C), 18.3, 18.2, -4.39, -4.52; IR (neat) 3500, 2930, 1473, 1250, 1131, 1077, 1025, 897, 838, $779 \mathrm{~cm}^{-1}$; HRMS (ES+) $\mathrm{m} / z$ for $\mathrm{C}_{19} \mathrm{H}_{32} \mathrm{O}_{4} \mathrm{NaSSi}[\mathrm{M}+\mathrm{Na}]^{+}$ calcd 407.1688, found 407.1673.

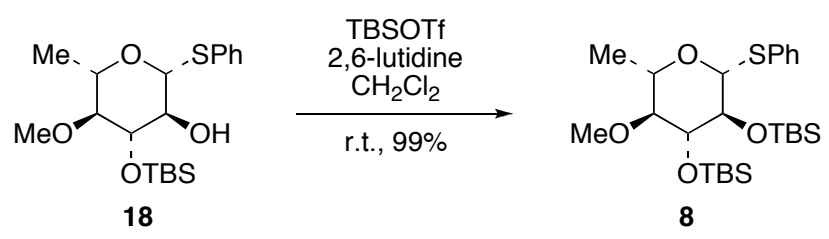

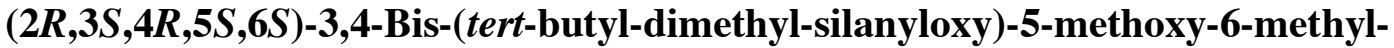

2-phenylsulfanyl-tetrahydro-pyran (8). To a solution of a secondary alcohol 18 (1.39 g, 3.62 $\mathrm{mmol})$ in $\mathrm{CH}_{2} \mathrm{Cl}_{2}(72.3 \mathrm{~mL})$ was added 2,6-lutidine (1.68 mL, $\left.14.4 \mathrm{mmol}\right)$ and TBSOTf (2.49 mL, 10.8 mmol) at $0{ }^{\circ} \mathrm{C}$. The resulting mixture was allowed to warm to room temperature and stirred for $16 \mathrm{~h}$. The mixture was then cooled with an ice bath, and $\mathrm{H}_{2} \mathrm{O}$ was added. The organic layer was separated and the aqueous layer was extracted with $\mathrm{CHCl}_{3}$. The combined organic layers were washed with $0.1 \mathrm{~N}$ $\mathrm{HCl}$ and with brine, dried, and concentrated. The crude product was purified by flash chromatography (hexane : EtOAc $=100: 1)$ to give the thioglycoside donor $8(1.79 \mathrm{~g}, 3.59 \mathrm{mmol}, 99 \%)$ as a colorless syrup: $[\alpha]_{\mathrm{D}}{ }^{23}=+47.8^{\circ}\left(c 1.92, \mathrm{CHCl}_{3}\right) ;{ }^{1} \mathrm{H} \mathrm{NMR}\left(400 \mathrm{MHz}, \mathrm{C}_{6} \mathrm{D}_{6}\right) \delta 7.61(\mathrm{~m}, 2 \mathrm{H}), 7.04(\mathrm{~m}, 2 \mathrm{H}), 6.96$ $(\mathrm{m}, 1 \mathrm{H}), 4.77(\mathrm{~d}, J=7.6 \mathrm{~Hz}, 1 \mathrm{H}), 3.81(\mathrm{dd}, J=7.4,6.3 \mathrm{~Hz}, 1 \mathrm{H}), 3.66(\mathrm{dd}, J=7.0,6.3 \mathrm{~Hz}, 1 \mathrm{H}), 3.37$ $(\mathrm{dq}, J=8.2,6.3 \mathrm{~Hz}, 1 \mathrm{H}), 3.17(\mathrm{~s}, 3 \mathrm{H}), 2.83(\mathrm{dd}, J=8.2,7.3 \mathrm{~Hz}, 1 \mathrm{H}), 1.24(\mathrm{~d}, J=6.3 \mathrm{~Hz}, 3 \mathrm{H}), 1.09$ (s, 9H), $1.08(\mathrm{~s}, 9 \mathrm{H}), 0.33(\mathrm{~s}, 3 \mathrm{H}), 0.24(\mathrm{~s}, 3 \mathrm{H}), 0.23(\mathrm{~s}, 3 \mathrm{H}), 0.22(\mathrm{~s}, 3 \mathrm{H}),{ }^{13} \mathrm{C} \mathrm{NMR}\left(100 \mathrm{MHz}, \mathrm{C}_{6} \mathrm{D}_{6}\right) \delta$ 136.5, 131.5 (2C), 129.1 (2C), 127.1, 89.2, 86.3, 78.0, 75.8, 75.3, 59.7, 26.8 (3C), 26.7 (3C), 19.7, 18.6, $18.5,-1.97,-2.58,-2.80,-3.14$; IR (neat) 2930, 1472, 1257, 1140, 1104, 1066, 839, $778 \mathrm{~cm}^{-1}$; HRMS $(\mathrm{ES}+) \mathrm{m} / \mathrm{z}$ for $\mathrm{C}_{25} \mathrm{H}_{46} \mathrm{O}_{4} \mathrm{NaSSi}_{2}[\mathrm{M}+\mathrm{Na}]^{+}$calcd 521.2553, found 521.2542. 


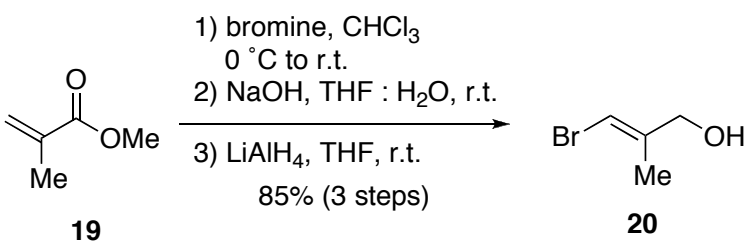

(E)-3-Bromo-2-methyl-prop-2-en-1-ol (20). To a solution of methyl methacrylate 19 (3.00 mL, $28.2 \mathrm{mmol})$ in $\mathrm{CHCl}_{3}(28.0 \mathrm{~mL})$ was added bromine $(1.59 \mathrm{~mL}, 31.1 \mathrm{mmol})$ at $0{ }^{\circ} \mathrm{C}$. The resultant mixture was stirred for $4 \mathrm{~h}$ at room temperature. The mixture was cooled to $0{ }^{\circ} \mathrm{C}$, and then aqueous $\mathrm{Na}_{2} \mathrm{~S}_{2} \mathrm{O}_{3}$ was added. The organic layer was separated and the aqueous layer was extracted with $\mathrm{CHCl}_{3}$. The combined organic layers were washed with brine, dried, and concentrated. The crude product, a colorless liquid, was used in the next reaction without purification.

To a solution of the above crude product in THF $(28.0 \mathrm{~mL})$ was added $\mathrm{NaOH}(4.52 \mathrm{~g}, 113$ $\mathrm{mmol})$ in $\mathrm{H}_{2} \mathrm{O}(28.0 \mathrm{~mL})$ at room temperature. The resulting mixture was stirred for $43 \mathrm{~h}$, then the mixture was acidified with $1 \mathrm{~N} \mathrm{HCl}$. The organic layer was extracted with $\mathrm{Et}_{2} \mathrm{O}$, the combined organic layers were washed with brine, dried, and concentrated. The crude product, obtained as a colorless solid, was used in the next reaction without purification.

To a mixture of $\mathrm{LiAlH}_{4}(1.58 \mathrm{~g}, 41.8 \mathrm{mmol})$ in $\mathrm{Et}_{2} \mathrm{O}(120 \mathrm{~mL})$ was slowly added the above crude product in $\mathrm{Et}_{2} \mathrm{O}(20 \mathrm{~mL})$ at room temperature. The resulting mixture was stirred for $2.5 \mathrm{~h}$ at this temperature. The mixture was then diluted $\mathrm{Et}_{2} \mathrm{O}(100 \mathrm{~mL})$ and treated with $\mathrm{H}_{2} \mathrm{O}(420 \mu \mathrm{L})$ and $15 \%$ aqueous $\mathrm{NaOH}(8 \mathrm{~mL})$ at $0{ }^{\circ} \mathrm{C}$. The mixture was allowed to warm to room temperature and stirred for $16 \mathrm{~h}$. To the mixture was added $\mathrm{Na}_{2} \mathrm{SO}_{4}$, and after being stirred for $30 \mathrm{~min}$, it was filtrated. The cake was washed with $\mathrm{Et}_{2} \mathrm{O}$ and the filtrate was concentrated. The crude product was purified by flash chromatography $\left(\mathrm{CHCl}_{3}\right)$ to give the known allylic alcohol $20(3.63 \mathrm{~g}, 24.0 \mathrm{mmol}, 85 \%)$ as a colorless liquid: ${ }^{1} \mathrm{H}$ NMR (400 MHz, $\mathrm{CDCl}_{3}$ ) $\delta 6.25$ (q, $\left.J=1.3 \mathrm{~Hz}, 1 \mathrm{H}\right), 4.10$ (s, 2H), 1.83 (d, $J=0.8 \mathrm{~Hz}, 3 \mathrm{H}$ ); ${ }^{13} \mathrm{C}$ NMR $\left(100 \mathrm{MHz}, \mathrm{CDCl}_{3}\right) \delta 141.1,104.2,66.8,16.7$; IR (neat) 3318, 2918, 1635, 1436, 1379, 1290 , $1068,1013,783,716 \mathrm{~cm}^{-1}$.

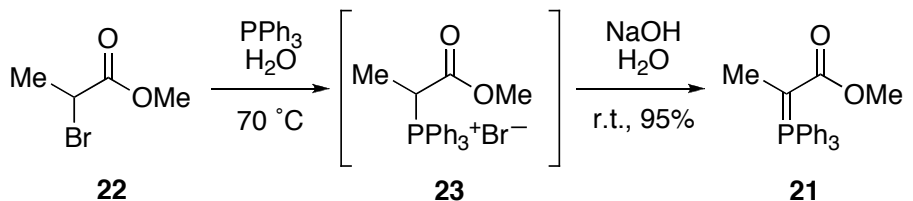

Methyl (triphenylphosphoranylidene)propionate (21). A mixture of triphenylphosphine (2.11 g, $8.06 \mathrm{mmol})$ and methyl bromopropionate $22(1.00 \mathrm{~mL}, 8.96 \mathrm{mmol})$ in $\mathrm{H}_{2} \mathrm{O}(8.9 \mathrm{~mL})$ was stirred for $24 \mathrm{~h}$ at $70{ }^{\circ} \mathrm{C}$. The mixture was cooled to room temperature, then a solution of $\mathrm{NaOH}(716$ $\mathrm{mg}, 17.9 \mathrm{mmol})$ in $\mathrm{H}_{2} \mathrm{O}(21 \mathrm{~mL})$ was added. The resulting mixture was stirred for 5 min at room temperature, then $\mathrm{CH}_{2} \mathrm{Cl}_{2}$ was added to dissolve the solid that formed. The organic layer was separated, and the aqueous layer was extracted with $\mathrm{CH}_{2} \mathrm{Cl}_{2}$. The combined organic layers were dried 
and concentrated. The solid residue was triturated with hexane, and filtered. The resulting solid was dried in vacuo to give the ylide 21 (2.66 g, $7.64 \mathrm{mmol}, 95 \%)$ as a yellow solid: ${ }^{1} \mathrm{H}$ NMR (400 MHz, $\left.\mathrm{CDCl}_{3}\right) \delta$ 7.28-7.90 (m, 15H), $3.61(43 \%)+3.13(57 \%)(\mathrm{s}, 3 \mathrm{H}), 1.62$ (major) $(\mathrm{d}, J=13.7 \mathrm{~Hz})+1.60$ (minor) (d, $J=14.3 \mathrm{~Hz})(3 \mathrm{H})$. Ref. ${ }^{3)}{ }^{1} \mathrm{H}$ NMR (200 MHz, $\left.\mathrm{CDCl}_{3}\right) \delta$ 7.4-7.9 (m, 15H), $3.61(40 \%)+$ $3.13(60 \%)(3 \mathrm{H}), 1.61(\mathrm{~d}, J=13.7 \mathrm{~Hz}, 3 \mathrm{H})$.

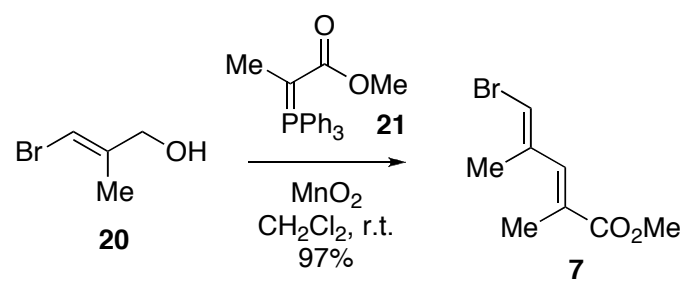

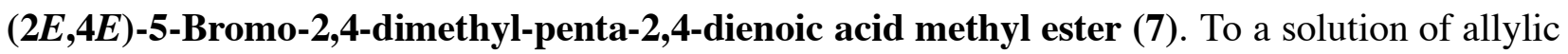
alcohol 20 (1.09 g, $7.21 \mathrm{mmol}$ ) and ylide 21 (3.01 g, $8.66 \mathrm{mmol}$ ) in $\mathrm{CH}_{2} \mathrm{Cl}_{2}\left(180 \mathrm{~mL}\right.$ ) was added $\mathrm{MnO}_{2}$ $(5.02 \mathrm{~g}, 57.7 \mathrm{mmol})$ at room temperature. The resultant mixture was stirred for $17 \mathrm{~h}$ and then filtrated through the Celite and the cake was washed with $\mathrm{CHCl}_{3}$. The filtrate was concentrated. The crude product was purified by flash chromatography (hexane : EtOAc $=25: 1$ ) to give the known bromodienoate 7 (1.54 g, $7.03 \mathrm{mmol}, 97 \%)$ as a slight yellow liquid: ${ }^{1} \mathrm{H}$ NMR (400 MHz, $\left.\mathrm{CDCl}_{3}\right) \delta$ 7.03 (s, 1H), 6.33 (s, 1H), 3.76 (s, 3H), 1.98 (s, 3H), 1.97 (s, 3H); $\left.{ }^{13} \mathrm{C} \mathrm{NMR} \mathrm{(100} \mathrm{MHz,} \mathrm{CDCl}{ }_{3}\right) \delta 168.7$, 138.5, 137.9, 128.1, 111.3, 52.1, 19.7, 14.2; IR (neat) 2951, 1716, 1435, 1251, 1119, 1024, $749 \mathrm{~cm}^{-1}$; HRMS (ES+) $m / z$ for $\mathrm{C}_{8} \mathrm{H}_{12} \mathrm{BrO}_{2}[\mathrm{M}+\mathrm{H}]^{+}$calcd 219.0021, found 219.0015. Ref. ${ }^{4)}{ }^{1} \mathrm{H} \mathrm{NMR}(600 \mathrm{MHz}$, $\left.\mathrm{CDCl}_{3}\right) \delta 7.00(\mathrm{~s}, 1 \mathrm{H}), 6.30(\mathrm{~m}, 1 \mathrm{H}), 3.73(\mathrm{~s}, 3 \mathrm{H}), 1.95(\mathrm{~d}, J=1.5 \mathrm{~Hz}, 3 \mathrm{H}), 1.94(\mathrm{~d}, J=1.5 \mathrm{~Hz}, 3 \mathrm{H})$; ${ }^{13} \mathrm{C}$ NMR $\left(150 \mathrm{MHz}, \mathrm{CDCl}_{3}\right) \delta 168.6,138.5,137.8,128.1,111.3,52.0,19.7,14.2$; IR (film) 3409, $1713,1631,1436,1249,1117,1020,791,748 \mathrm{~cm}^{-1}$.
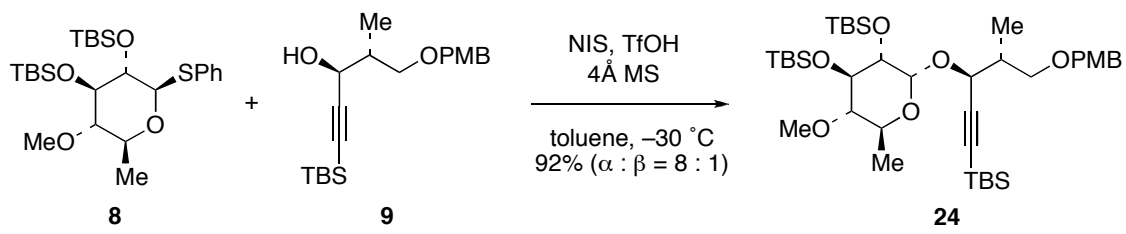

$(2 R, 3 S, 4 R, 5 S, 6 S)-2-\{(S)-3-($ tert-Butyl-dimethyl-silanyl)-1-[(R)-2-(4-methoxy-benzyloxy)-1methyl-ethyl]-prop-2-ynyloxy\}-3,4-bis-(tert-butyl-dimethyl-silanyloxy)-5-methoxy-6-methyl-tetra hydro-pyran (24). A mixture of thioglycoside 8 (1.76 g, $3.53 \mathrm{mmol})$, propargylic alcohol 9 (1.84 g, $5.30 \mathrm{mmol})$, and $4 \AA$ molecular sieves $(3.52 \mathrm{~g})$ in toluene $(118 \mathrm{~mL})$ was stirred for $2 \mathrm{~h}$ at room temperature. The resultant mixture was cooled to $-30{ }^{\circ} \mathrm{C}$, and then $N$-iodosuccinimide $(1.98 \mathrm{~g}, 8.83$ $\mathrm{mmol})$, and trifluoromethanesulfonic acid in toluene $(5.30 \mathrm{~mL}, 530 \mu \mathrm{mol}, 0.1 \mathrm{M})$ were added. The reaction mixture was stirred for $1 \mathrm{~h}$ at $-30{ }^{\circ} \mathrm{C}$. The mixture was then diluted with saturated aqueous $\mathrm{NaHCO}_{3}$, and then mixture was warmed to ambient temperature and filtered. The organic layer was extracted with EtOAc, washed with $0.2 \mathrm{~N}$ aqueous $\mathrm{Na}_{2} \mathrm{~S}_{2} \mathrm{O}_{3}$ and with brine, dried, and concentrated. 
The crude product was purified by flash chromatography (hexane : EtOAc $=80: 1$ to $60: 1$ ) to give a glycoside $24(2.40 \mathrm{~g}, 3.26 \mathrm{mmol}, 92 \%)$ as a colorless syrup: $[\alpha]_{\mathrm{D}}{ }^{23}=-64.1^{\circ}\left(c 0.59, \mathrm{CHCl}_{3}\right) ;{ }^{1} \mathrm{H} \mathrm{NMR}$ $\left(400 \mathrm{MHz}, \mathrm{C}_{6} \mathrm{D}_{6}\right) \delta 7.24(\mathrm{~d}, J=8.6 \mathrm{~Hz}, 2 \mathrm{H}), 6.82(\mathrm{~d}, J=8.6 \mathrm{~Hz} 2 \mathrm{H}), 5.42(\mathrm{~d}, J=3.4 \mathrm{~Hz}, 1 \mathrm{H}), 4.98(\mathrm{~d}$, $J=3.6 \mathrm{~Hz}, 1 \mathrm{H}), 4.41(\mathrm{~d}, J=11.4 \mathrm{~Hz}, 1 \mathrm{H}), 4.31(\mathrm{~d}, J=11.4 \mathrm{~Hz}, 1 \mathrm{H}), 4.07(\mathrm{t}, J=8.9 \mathrm{~Hz}, 1 \mathrm{H}), 3.79$ (dq, $J=9.6,6.2 \mathrm{~Hz}, 1 \mathrm{H}), 3.74(\mathrm{dd}, J=9.1,3.4 \mathrm{~Hz}, 1 \mathrm{H}), 3.58(\mathrm{t}, J=8.8 \mathrm{~Hz}, 1 \mathrm{H}), 3.34(\mathrm{dd}, J=9.0,5.5 \mathrm{~Hz}$, $1 \mathrm{H}), 3.33(\mathrm{~s}, 3 \mathrm{H}), 3.28(\mathrm{~s}, 3 \mathrm{H}), 2.62(\mathrm{dd}, J=9.2,9.1 \mathrm{~Hz}, 1 \mathrm{H}), 2.29(\mathrm{~m}, 1 \mathrm{H}), 1.21(\mathrm{~d}, J=6.9 \mathrm{~Hz}, 3 \mathrm{H})$, $1.17(\mathrm{~d}, J=6.2 \mathrm{~Hz}, 3 \mathrm{H}), 1.13(\mathrm{~s}, 18 \mathrm{H}), 0.99(\mathrm{~s}, 9 \mathrm{H}), 0.33(\mathrm{~s}, 3 \mathrm{H}), 0.32(\mathrm{~s}, 3 \mathrm{H}), 0.25(\mathrm{~s}, 3 \mathrm{H}), 0.23(\mathrm{~s}$, $3 \mathrm{H}), 0.15$ (s, 3H), 0.13 (s, 3H); ${ }^{13} \mathrm{C}$ NMR (100 MHz, $\left.\mathrm{C}_{6} \mathrm{D}_{6}\right) \delta$ 159.7, 131.1, 129.5 (2C), 114.0 (2C), 104.7, 95.5, 90.1, 87.8, 74.9, 74.6, 73.0, 71.8, 67.8, 64.3, 61.0, 54.8, 39.6, 26.9 (3C), 26.8 (3C), 26.3 (3C), 18.6, 18.5, 18.4, 16.8, 12.2, -2.77, -3.14, -3.54, -3.61, -4.35, -4.37; IR (neat) 2930, 2170, 1613, 1514, 1463, 1250, 1098, 1032, 839, $759 \mathrm{~cm}^{-1}$; HRMS (ES+) $m / z$ for $\mathrm{C}_{39} \mathrm{H}_{72} \mathrm{O}_{7} \mathrm{NaSi}_{3}[\mathrm{M}+\mathrm{Na}]^{+}$calcd 759.4484 , found 759.4486 .

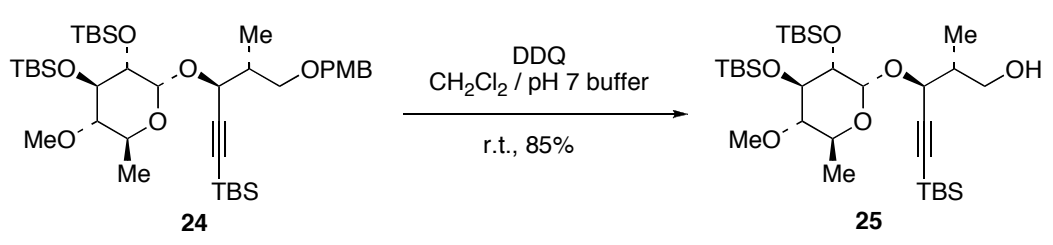

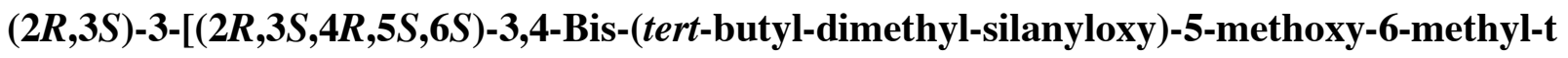
etrahydro-pyran-2-yloxy]-5-(tert-butyl-dimethyl-silanyl)-2-methyl-pent-4-yn-1-ol (25). $\quad$ To a mixture of glycoside $24(2.38 \mathrm{~g}, 3.23 \mathrm{mmol})$ in $\mathrm{CH}_{2} \mathrm{Cl}_{2}(64.7 \mathrm{~mL})$ and $\mathrm{pH} 7.0$ buffer $(12.9 \mathrm{~mL})$ was added DDQ (1.47 g, $6.46 \mathrm{mmol})$ at room temperature, and the resultant mixture was stirred for $1 \mathrm{~h}$. This mixture was then diluted with saturated aqueous $\mathrm{NaHCO}_{3}$. The organic layer was separated and the aqueous layer was extracted with $\mathrm{CHCl}_{3}$. The combined organic layers were washed with brine, dried, and concentrated. The crude product was purified by flash chromatography (hexane : EtOAc = $20: 1$ to $10: 1)$ to give primary alcohol $25(1.70 \mathrm{~g}, 2.76 \mathrm{mmol}, 85 \%)$ as a colorless solid: $[\alpha]_{\mathrm{D}}{ }^{23}=$ $-85.0^{\circ}$ ( $c 1.24, \mathrm{CHCl}_{3}$ ); $\mathrm{mp} 113{ }^{\circ} \mathrm{C} ;{ }^{1} \mathrm{H} \mathrm{NMR}\left(400 \mathrm{MHz}, \mathrm{CDCl}_{3}\right) \delta 5.14(\mathrm{~d}, J=3.4 \mathrm{~Hz}, 1 \mathrm{H}), 4.51(\mathrm{~d}, J=$ $4.2 \mathrm{~Hz}, 1 \mathrm{H}), 3.92(\mathrm{~m}, 1 \mathrm{H}), 3.73(\mathrm{t}, J=8.9 \mathrm{~Hz}, 1 \mathrm{H}), 3.57(\mathrm{dd}, J=9.1,3.4 \mathrm{~Hz}, 1 \mathrm{H}), 3.47(\mathrm{~s}, 3 \mathrm{H})$, 3.44-3.55 (m, 2H), $2.96(\mathrm{dd}, J=9.8,2.2 \mathrm{~Hz}, 1 \mathrm{H}), 2.66(\mathrm{dd}, J=9.2,9.1 \mathrm{~Hz}, 1 \mathrm{H}), 2.22(\mathrm{~m}, 1 \mathrm{H}), 1.28(\mathrm{~d}$, $J=6.3 \mathrm{~Hz}, 3 \mathrm{H}), 0.91-0.95(\mathrm{~m}, 30 \mathrm{H}), 0.12(\mathrm{~s}, 3 \mathrm{H}), 0.11(\mathrm{~s}, 6 \mathrm{H}), 0.10(\mathrm{~s}, 6 \mathrm{H}), 0.07(\mathrm{~s}, 3 \mathrm{H}) ;{ }^{13} \mathrm{C} \mathrm{NMR}$ $\left(100 \mathrm{MHz}, \mathrm{CDCl}_{3}\right) \delta 100.8,95.1,92.3,86.9,73.8$ (2C), 69.8, 67.8, 65.6, 61.3, 39.2, 26.4 (6C), 26.1 (3C), 18.2, 18.1, 18.0, 16.5, 13.3, -3.26, -3.60,-3.82, -4.09, -4.61, -4.63; IR (neat) 3499, 2929, 2173, 1471, 1250, 1092, 1069, 1018, 836, $773 \mathrm{~cm}^{-1}$; HRMS (ES+) m/z for $\mathrm{C}_{31} \mathrm{H}_{64} \mathrm{NaO}_{6} \mathrm{Si}_{3}[\mathrm{M}+\mathrm{Na}]^{+}$calcd 639.3908, found 639.3923. 


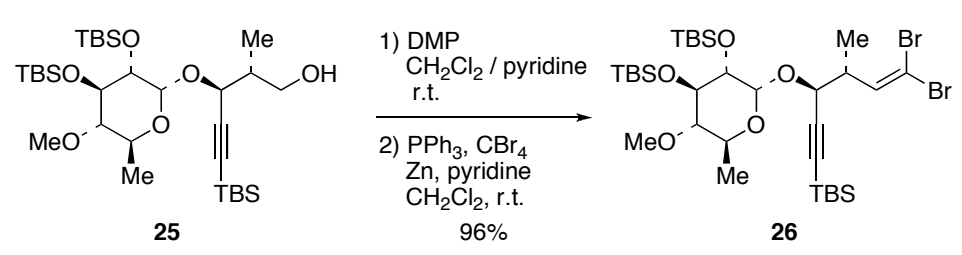

$(2 R, 3 S, 4 R, 5 S, 6 S)$-3,4-Bis-(tert-butyl-dimethyl-silanyloxy)-2-\{(1S,2R)-4,4-dibromo-1-[(tert-b utyl-dimethyl-silanyl)-ethynyl]-2-methyl-but-3-enyloxy\}-5-methoxy-6-methyl-tetrahydro-pyran

(26). To a solution of a primary alcohol $25(38.2 \mathrm{mg}, 62.0 \mu \mathrm{mol})$ in $\mathrm{CH}_{2} \mathrm{Cl}_{2}(1.2 \mathrm{~mL})$ and pyridine $(60 \mu \mathrm{L})$ was added Dess-Martin periodinane $(39.5 \mathrm{mg}, 93.0 \mu \mathrm{mol})$ at room temperature, and the resultant mixture was stirred for $15 \mathrm{~min}$. The mixture was then diluted with aqueous $\mathrm{Na}_{2} \mathrm{~S}_{2} \mathrm{O}_{3}$. The organic layer was extracted with $\mathrm{CHCl}_{3}$, washed with brine, dried, and concentrated. The crude product was used in the next reaction without purification.

To $0{ }^{\circ} \mathrm{C}$ a mixture of triphenylphosphine $(237 \mathrm{mg}, 904 \mu \mathrm{mol})$ and zinc $(59.1 \mathrm{mg}, 904 \mu \mathrm{mol})$ in $\mathrm{CH}_{2} \mathrm{Cl}_{2}(2.26 \mathrm{~mL})$ was added $\mathrm{CBr}_{4}(300 \mathrm{mg}, 904 \mu \mathrm{mol})$. The resultant mixture was allowed to warm to room temperature and stirred for $17 \mathrm{~h}$. Pyridine $(73 \mu \mathrm{L}, 904 \mu \mathrm{mol})$ was then added at the same temperature. After $15 \mathrm{~min}$, the mixture $(1.39 \mathrm{~mL})$ was added to the solution of the above crude aldehyde in $\mathrm{CH}_{2} \mathrm{Cl}_{2}(2.1 \mathrm{~mL})$ at room temperature. The resultant mixture was stirred for $10 \mathrm{~min}$, and then saturated aqueous $\mathrm{NH}_{4} \mathrm{Cl}$ was poured. The organic layer was extracted with $\mathrm{CHCl}_{3}$, washed with brine, dried, and concentrated. The residue was filtered through silica gel and the filtrate was concentrated. The crude product was purified by flash chromatography (hexane : EtOAc $=100: 1$ ) to give dibromoolefin $26(46.0 \mathrm{mg}, 59.7 \mu \mathrm{mol}, 96 \%)$ as a slightly yellow oil: $[\alpha]_{\mathrm{D}}{ }^{23}=-104.6^{\circ}(c 0.99$, $\left.\mathrm{CHCl}_{3}\right) ;{ }^{1} \mathrm{H}$ NMR $\left(400 \mathrm{MHz}, \mathrm{CDCl}_{3}\right) \delta 6.39(\mathrm{~d}, J=9.5 \mathrm{~Hz}, 1 \mathrm{H}), 5.04(\mathrm{~d}, J=3.4 \mathrm{~Hz}, 1 \mathrm{H}), 4.25(\mathrm{~d}, J=$ $5.2 \mathrm{~Hz}, 1 \mathrm{H}), 3.81(\mathrm{t}, J=8.9 \mathrm{~Hz}, 1 \mathrm{H}), 3.55(\mathrm{dd}, J=9.1,3.4 \mathrm{~Hz}, 1 \mathrm{H}), 3.48(\mathrm{~s}, 3 \mathrm{H}), 3.46(\mathrm{dq}, J=9.6,6.3$ $\mathrm{Hz}, 1 \mathrm{H}), 2.86(\mathrm{~m}, 1 \mathrm{H}), 2.66(\mathrm{dd}, J=9.2,9.1 \mathrm{~Hz}, 1 \mathrm{H}), 1.28(\mathrm{~d}, J=6.3 \mathrm{~Hz}, 3 \mathrm{H}), 1.13(\mathrm{~d}, J=6.9 \mathrm{~Hz}, 3 \mathrm{H})$, 0.93 (s, 27H), 0.12 (s, 3H), 0.11 (s, 3H), 0.10 (s, 9H), 0.09 (s, 3H); $\left.{ }^{13} \mathrm{C} \mathrm{NMR} \mathrm{(100} \mathrm{MHz,} \mathrm{CDCl}_{3}\right) \delta$ 139.5, 101.4, 95.3, 91.6, 89.5, 87.1, 73.9, 73.6, 67.7, 67.2, 61.2, 42.9, 26.5 (3C), 26.4 (3C), 26.1 (3C), 18.3, 18.1, 18.0, 16.4, 15.3, -3.19, -3.57, -3.87, -4.09, -4.62, -4.65; IR (neat) 2930, 2171, 1471, 1252 , $1105,1033,839,760,669 \mathrm{~cm}^{-1}$; HRMS (ES+) $\mathrm{m} / z$ for $\mathrm{C}_{32} \mathrm{H}_{62} \mathrm{Br}_{2} \mathrm{NaO}_{5} \mathrm{Si}_{3}[\mathrm{M}+\mathrm{Na}]^{+}$calcd 791.2170, found 791.2191 .

\section{References Cited in the Supporting Information}

(1) Haack, K.-J.; Hashiguchi, S.; Fujii, A.; Ikariya, T.; Noyori, R. Angew. Chem. Int. Ed. 1997, $36,285$.

(2) Murray, R.W.; Singh, M. Org. Synth., Col. Vol. IX 1998, 288.

(3) Werkhoven, T. M.; van Nispen, R.; Lugtenburg, J. Eur. J. Org. Chem. 1999, 2909.

(4) Nicolaou, K. C.; Fylaktakidou, K. C.; Monenschein, H.; Li, Y.; Weyershausen, B.; Mitchell, H. J.; Wei, H.; Guntupalli, P.; Hepworth, D.; Sugita, K. J. Am. Chem. Soc. 2003, 125, 15433. 